\title{
The Effect Of Promotion On Interest In Opening An Account At Bank Muamalat, Palu Branch
}

\author{
Gita Dolita1 , Hilal Malarangan'2, Malkan ${ }^{3}$ \\ 1,2,3Institut Agama Islam Negeri Palu, Palu, Indonesia. \\ gitadolita1501@gmail.com
}

\begin{abstract}
Purpose - The purpose of this study was to determine whether promotion has an effect on the interest of Islamic banking students in opening an account at the hammer branch of the muamalat bank and to find out how significant the effect of promotion is on student interest in opening an account at the hammer branch of the muamalat bank.

Method - This study uses primary data, namely a questionnaire that uses a Likert scale as a calculation scale. The sample of this study was 485 students of the Faculty of Economics and Islamic Business IAIN Palu, Department of Islamic Banking from class 2016 to class 2018. To analyse the data, the authors used multiple linear regression methods and SPSS version 21.

Result - Research result shows that the magnitude of the influence of the variable $(X)$ on the variable $(Y)$ is 0.388 or $38.8 \%$. These results can provide an illustration that respondents view that promotion can influence interest in opening an account at a muamalat bank and promotion has a significant effecton studentinterestin openingan accountata muamalatbank. it can be seen that the promotion variable $(X)$ has avalue of count $3.783>$ ttable 1.663 and has a significant value (sig) of 0.000 in the coefficients table with a value of $\alpha$ (significant level) 0.05 . This means $0.000<0.05$.

Implication - This study is only limited to using data from several students in one university.

Originality - The difference with previous research is in the location and object under study.
\end{abstract}

Keywords: Promotion; Interest in Opening an Account. 
Gita Dolita, Hilal Malarangan, Malkan

\section{Introduction}

Banking institutions are financial intermediaries that have a very vital role in the structure of the country's economy. Banks absorb public funds and channel them back to the community. The role of banks is so strategic in building the country's economy, so that every country tries to create a banking system that is healthy, resilient, and can maintain public trust (Darma, 2013).

Islamic banks in Indonesia have obtained legitimacy in banking law Number 7 of 1992 which was later amended by banking law Number 10 of 1998. Banks, both conventional and Islamic banks, always operate by saving funds from creditors and lending these funds. to the debtor. Islamic banks prefer capital financing rather than debt and asset-based financing (Mashilal, 2020). Management of customer funds collected in third party fund sources (DPK) by Islamic banks must be able to be managed by allocating them to productive posts (Ana \& Lathif, 2020). The implementation of this alternative is the development of bank business activities based on sharia principles whose operations are not based on the interest method, but on the profit sharing method (Soemitra, 2004).

Indonesia as a country with the largest Muslim population should be the largest potential customer in the Islamic financial industry, including in Islamic banking. Sharia banking is currently experiencing a very rapid development in Indonesia, marked by the increasing number of third party funds, opening of head offices, branch offices and Islamic banking networks, making it easier for people to save their funds. (Rosyadah et al., 2020). The existence of this Islamic bank in Indonesia, which was born in 1992, certainly gave a new face to the development of national banking, namely Bank Muamalat Indonesia (BMI). PT. Bank Muamalat Indonesia Tbk ("Bank Muamalat Indonesia") started its business journey as the first Islamic Bank in Indonesia on November 1, 1991 or 24 Rabi'us Tsani $1412 \mathrm{H}$. The establishment of Bank Muamalat Indonesia was initiated by the Indonesian Ulema Council (MUI), the Indonesian Muslim Intellectuals Association. (ICMI) and Muslim entrepreneurs who later received support from the Government of the Republic of Indonesia. In 1994, it has 
The Effect Of Promotion On Interest In ...

become a foreign exchange bank. The existing funding products use the principles of Wadiah (deposit) and mudharabah (profit sharing). Meanwhile, the investment of funds uses the principles of sale and purchase, profit sharing, and leasing (Bank Muamalat Indonesia, 2020).

Saving is an action recommended by the religion of Islam, because by saving means a person prepares himself for long-term planning for his future life as well as to be on the lookout for unwanted things in the future. In Indonesia, there are two banks, namely Islamic banks and conventional banks. In this era, many people are more likely to save at conventional banks, because people do not really understand Islamic banks and some are not even familiar with Islamic banks. Islamic banks are banks that are based on, among others: on the principles of partnership, fairness, transparency and universality as well as conducting banking business activities. based on sharia principles.

Promotion is one of the determining factors for the success of a marketing program. In such fierce competition, companies can not only rely on improving the quality and development of service products, even though the quality of a product, if consumers have never known it and are not sure if the product will be of use to them, then they will never buy it. Products produced by the company in order to be well recognized and ultimately purchased by consumers, the company needs to carry out promotional activities, which consist of advertising, sales promotion, personal selling, public relations, and direct marketing. Therefore, the bank must be able to properly and properly utilize the promotional media used such as advertisements in print media, and so on.

Islamic banks are required to be able to predict and use promotional media that are easiest for the public to understand so that targets can be achieved as expected. Promotional activities include offering products owned by a bank to the public through print and electronic media and so on. With the promotion of bank products, the public can find out what is provided and provided by the bank and increase public interest in saving at the bank (Alhifni \& Ortega, 2017). Sharia banks apply two contracts in savings, namely the wadiah and mudharabah contracts (Putri, 2020). 
Gita Dolita, Hilal Malarangan, Malkan

Saryadi and Suryoko (2013) state that the better the knowledge of Islamic banks, the higher the likelihood of having a relationship with Islamic banks.

Interest is described as a person's condition before taking an action, which can be used as a basis for predicting that behavior or action. Interest in saving is assumed to be an interest in buying which is a behavior that appears in response to objects that indicate a customer's desire to make a purchase. This is because conventional banks appear earlier than Islamic banks. The development of the sharia-based industry. Therefore, the understanding of Islamic banking is needed in the community. Based on the results of the research, it shows that Islamic Banks carry out several strategies to meet the achievement of their targets for the community, one of the targets is students.

Muamalat bank branch office in Palu City, Central Sulawesi Province. It is one of the branch offices of Bank Muamalat in Indonesia. This office serves customers for various needs related to Bank Muamalat products such as applying for credit and loans, cash deposits, deposits, creating bank accounts, applying for bank muamalat mortgages or mortgages, to mobile online banking.

However, the reality in the field is that there are still only a few students of IAIN Palu, majoring in Islamic Banking, who save at Sharia Banks and even some students who are still saving at conventional banks. Based on the results of interviews regarding knowledge of Islamic banking and its systems as well as the final results of the implementation carried out by researchers to several Sharia Banking Department students at IAIN Palu, it can be concluded that they already understand and understand the prohibition of usury, the importance of Islamic banking and the Islamic banking system and besides In terms of knowledge about Islamic banking, to attract public interest in saving at Sharia Banks, one of the strategies implemented is in the form of promotion.

\section{Literature Review}

Promotion 
The Effect Of Promotion On Interest In ...

Promotion is the most powerful means of attracting and retaining its customers, one of the objectives of bank promotion is to inform all types of products offered and try to attract new potential customers (Rusliani, 2017).

The quality of a product, if consumers have never heard of it and are not sure that the product will be of use to them, then they will never buy it. In essence, promotion is a form of marketing communication, namely a marketing activity that seeks to disseminate information, influence / persuade, and / or remind the target market of the company and its products in order to accept, buy and be loyal to the products that the company has offered in question (Fandy, 1998).

\section{Interest}

According to Djamarah (2004), interest is a persistent tendency to pay attention to and remember several activities. Someone who is interested in an activity will pay attention to that activity consistently with pleasure.

The factors that influence the emergence of interest can be divided into two, namely (Saleh \& Wahab, 2004): 1) The influence from within the individual itself includes; Weight, age, gender, experience, feelings of ability, personality; 2) Influences from outside the individual include; family environment, school environment namely knowledge, and community environment.

\section{Hypothesis}

H1 = Promotion has an effect on student interest in opening an account at Bank Muamalat; H2 = Promotion has no effect on student interest in opening an account at Bank Muamalat. deposits.

\section{Methods}

The type of research used is verification research, which is research conducted on a specific population or sample with the aim of testing the predetermined hypothesis (Sugiyono, 2013, 2018). The population in this study were all students of the Islamic Banking Department from Class 2016 to 
Gita Dolita, Hilal Malarangan, Malkan

Class 2018. Based on the sampling technique taken by researchers in this study, there were 83 samples of students from the Faculty of Economics and Islamic Business, Department of Islamic Banking.

\section{Results and Discussion}

\section{Normality test}

The results of the normality test can be seen in the following table 1. From the table above the results of the Kolmogorov-Smirnov normality test can be seen to be normally distributed. This is evidenced by the value (Asymp.Sig.2tailed) on the variable work experience, education, work motivation and employee performance greater than 0.05 , namely $0.128>0.05$. So it can be said that the data is normally distributed.

\section{Heterokesdasticity Test}

The results of the heteroscedasticity test can be seen in the following table 2. The classic assumption heteroscedasticity test is used to determine whether or not the classic assumption heteroscedasticity is the residual variant inequality for all observations in the regression model. A good regression model should not allow heteroscedasticity. To test for heteroscedasticity, this study used the Glejser test by regressing the absolute residual values of the independent variables. If the significant count is greater than alpha $=5 \%$, then there is no heteroscedasticity problem.

Table 1. Normality Test One-Sample Kolmogorov-Smirnov Test

\begin{tabular}{ccc}
\hline & & ABSOLUT_RES_1 \\
\hline \multirow{2}{*}{ Normal Parametersa, b } & Mean & 83 \\
& Std. Deviatioln & 2,3495 \\
Most Extreme Differences & Absolute & 1,71943 \\
& Positive &, 128 \\
& Negative &, 128 \\
Kolmogorov-Smirnov Z &,- 087 \\
Asymp. Sig. (2-tailed) & 1,170 \\
\hline
\end{tabular}


The Effect Of Promotion On Interest In ...

Table 2. Heterokesdasticity Test

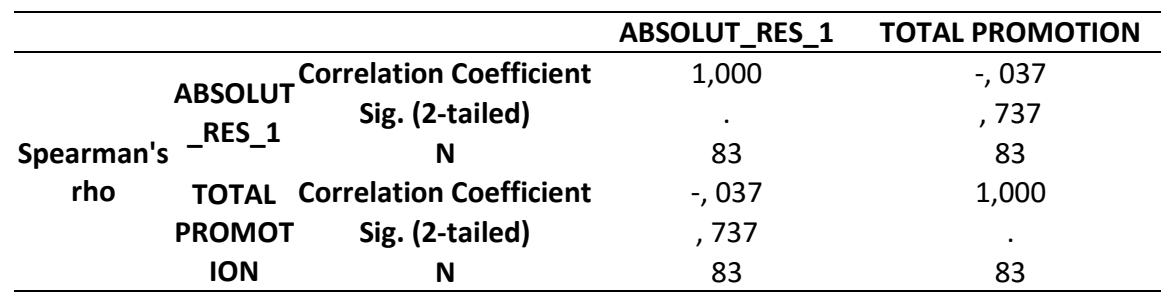

However, if the significant value is smaller than alpha $=5 \%$, it can be concluded that the regression model heteroscedasticity occurs. The existence of heteroscedasticity can be seen by looking at the plot graph between the prediction of the dependent variable (ZPRED) and the residual (ZRESID).(Divine and Afendi, 2019).

Based on table 2 the results of the heteroscedasticity test show the significance value of variable X (Promotion) of 0.737 . Of these variables has a significant value of more than 0.05 , it can be said that this study does not have heteroscedasticity.

\section{Multiple Regression Test}

Multiple liner regression is used to measure the influence of independent variables with more than one variable on the dependent variable and to predict the dependent variable using the independent variable. Kuncoro (2001: 26) defines regression analysis as a study of the relationship of one variable which is called the explained variable with one or two variables that explain (the explanatory).

Table 3. Multiple Regression Test

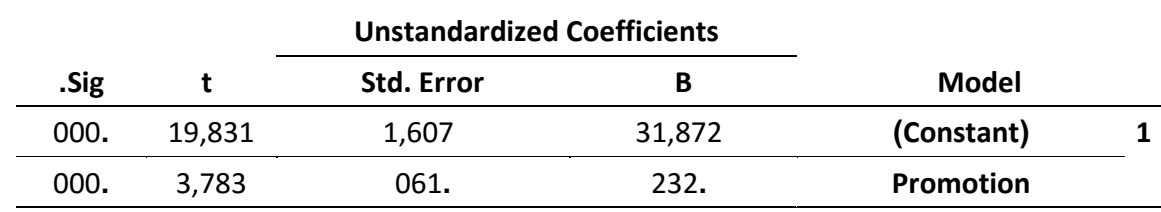


Gita Dolita, Hilal Malarangan, Malkan

The results of data processing, then the equation for multiple linear regression in this study can be written as follows:

$$
\mathrm{Y}=31,872+0.232 \mathrm{X}+\mathrm{e}
$$

\section{The Effect of Promotion on Interest in Opening an Account}

The effect of promotion on the interest in opening an account can be seen from the statistical test results obtained by the value of tcount 3,783> ttable 1,663 and has a significant value (sig) of 0,000 on the coefficients table with a value of $\alpha$ (significant level) 0.05 . This means that $0.000<0.05$, with this value means that the promotional variable $(X)$ has a significant influence on the interest in opening an account (Y). The amount of influence can be seen in the Beta column. The magnitude of the influence of the variable $(\mathrm{X})$ on the variable (Y) is 0.388 or $38.8 \%$. These results can provide an idea that the respondent (student) views that promotion is able to influence student interest in opening an account at a muamalat bank.

In accordance with the results of the respondents' answers that there are 38 respondents or $45.8 \%$ who strongly agree with the statement that I am interested in opening an account at the Muamalat bank because they are interested in the advertisements made by Muamalat Bank. This can be an encouragement for students to open an account at a muamalat bank.

Based on the results of the analysis of the respondents' answers, promotion should be one of the reasons for students to open an account at a Muamalat bank, because the more specific the promotion of an institution, the higher the student's interest in opening an account at the Muamalat bank.

Promotion is a component that is used to inform and

influencing the market for the company's products, so that the market can find out about the products produced by the company. The activities included in promotional activities are advertising, personal selling, sales promotion and publicity. With promotion, it is basically expected to be able to make demand inelastic when prices rise and make it elastic when prices fall. 
The Effect Of Promotion On Interest In ...

\section{Conclusion}

Based on the results of research and discussion conducted by researchers in the previous chapter about the effect of promotion. The conclusions that can be drawn are: 1) Promotion has a positive and significant effect on student interest in opening an account at the Muamalat bank, that is, the better the promotion carried out by Bank Muamalat Palu, the students' interest in opening an account at the Muamalat bank has also increased. accepted.

\section{References}

Alhifni, \& Ortega. (2017). Pengaruh Media Promosi Perbankan Syariah Terhadap Minat Menabung Masyarakat di Bank Syariah. Jurnal Ekonomi Syariah.

Ana, \& Lathif. (2020). Variables Determining For Impairment On Productive Assets In Islamic Banks In Indonesia. Jurnal Al-Arbah.

Bank Muamalat Indonesia. (2020). Profil Bank Muamalat. www.bankmuamalat.co.id

Cahya Rosyadah, P., Rachmat Arifin, N., Muhtadi, R., \& Safik, M. (2020). Factors That Affect Savings In Islamic Banking. Journal of Islamic Finance and Banking, 2(1), 33-46. https://doi.org/10.21580/alarbah.2020.2.1.5499

Darma. (2013). Pengaruh Bauran Promosi Terhadap Keputusan Pembelian Produk Pembiayaan KPR Platinum Ib Pada Bank X Syariah Cabang Harmoni Jakarta. Jurnal Ekonomi Dan Bisnis, 12(1)

Fandy, T. (1998). Peranan Desain Kemasan Dalam Dunia Pemasaran (2nd ed.). Andi.

Ilahi, A. P., \& Afendi, A. (2019). Factors To Influence Employee Performance In Bank Tabungan Negara Sharia Semarang. ALARBAH: Journal of Islamic Finance and Banking, 1(1), 1. https://doi.org/10.21580/al-arbah.v1i1.4108

Mashilal. (2020). . Risk Of Sharia Banking In Indonesia: Viewed From 
Gita Dolita, Hilal Malarangan, Malkan

Types Of Financing. Jurnal Al-Arbah.

Putri. (2020). Factors That Affect Savings In Islamic Banking. Jurnal AlArbah.

Rusliani. (2017). Analisis ,Model Promosi Bank Muamalat Indonesia. Jurnal: Ekonomi Islam, 8.

AL-ARBAH | 46 Saleh, A. R., \& Wahab, M. A. (2004). Psikologi Suatu Pengantar Dalam Perspektif Islam (1st ed.). Prenada Media.

Soemitra, A. (2004). Bank dan Lembaga Syariah. Cet 1. Kencana Prenada Media Grup.

Sugiyono. (2013). Metode Penelitian Kuantitatif Kualitatif dan R\&D. Cet. XIX. Alfabeta.

Sugiyono. (2018). Metode Penelitian Kuantitatif, Kualitatif, dan R\&D.

Suryoko, \& Saryadi. (2013). Pengaruh Kelompok Acuan dan Pengetahuan Tentang Perbankan Syariah Terhadap Minat Menabung di Perbankan Syariah. Jurnal Ilmu Administrasi. 